DOI: $10.21802 /$ artm.2020.1.13.162.

УДК 378.147.+614.253.4+376.68

\title{
ДОСВІД ПРОВЕДЕННЯ НАУКОВОГО ГУРТКА ДЛЯ СТУ ДЕНТІВ ФАКУЛЬТЕТУ ПІДГОТОВКИ ІНОЗЕМНИХ ГРОМАДЯН У ПРОФЕСІЙНІЙ ПІДГОТОВЦІ ЛІКАРЯ
}

\author{
Н.В. Савчук
}

Івано-Франківський національний медичний університет, кафедра внутрішньої медицини №2 та медсестринства, м. Івано-Франківськ, Украӥна,

ORCID ID: 0000-0002-8885-5796, e-mail: savchuk.natalja257@gmail.com

Резюме. У статті розкривається проблема додаткового навчання студентів факультету підготовки іноземних громадян у студентському науковому гуртку та відзначено можливість багатогранного впливу на формування лікаря як особистості, що буде мати велике значення для розвитку та розкриття індивідуального потенціалу й значне підвищення якості майбутнього фахівця.

Розглядаються не тільки позитивні сторони поведінки лікаря, а саме формування деонтологічних принципів майбутніх фахівців, зокрема демонстрування дії теплого, співчутливого слова на пацієнта, але й можливі близькі чи віддалені негативні результати, за яких слід враховувати особливості особистості хворого, сприйняття ним інформації, наданої всім медичним персоналом. Студенти факультету підготовки іноземних громадян, згідно з графіком чергувань, можуть не «самостійно», а зі своїм наставником освоювати знання та практичні навички з терапії та догляду за хворими терапевтичного профілю.

Під час проведення засідань наукового гуртка наголошується на необхідності щоденного поповнення знань, удосконалення своєї майстерності та невпинного самовдосконалення. Студенти іноземного факультету залучаються до організації та проведення семінарів-практикумів, тренінгів та майстер-класів 3 внутрішньої медицини, на яких учасники можуть практикувати основні терапевтичні маніпуляції з фаховими коментарями наставника.

Навчання в межах студентського гуртка дозволяє плідно реалізовувати навчальну, виховну та розвиваючу функції педагогічного процесу, сприяє активному формуванню знань в іноземних студентів через самостійну роботу та колективне обговорення, творче мислення, розвиває інтелектуальні вміння, а також дозволяє активно формувати професійні якості майбутніх фахівців.

Ключові слова: науковий гурток, студент, медицина, освіта, наука.

Обгрунтування дослідження. Реформа вищої медичної школи в Україні в рамках Болонської декларації спрямована на створення загальноєвропейської конкурентоздатної системи освіти з єдиними вимогами і стандартами, світове визнання дипломів, вільний вибір місця навчання та працевлаштування [2, с. 353]. Перехід викладання від традиційної до кредитно-модульної системи організації навчального процесу вимагає не тільки суто організаційних заходів, створення нової методичної бази, але й якісних змін усієї системи навчання. Для адекватної професійної підготовки лікаря необхідно застосовувати комплексний практично-орієнтовний навчальнометодологічний підхід, який забезпечує засвоєння студентами факультету підготовки іноземних громадян базових знань із внутрішньої медицини [3, с. 186]. Для студента-медика важливо не лише осмислити та засвоїти інформацію, а й оволодіти способами іiі практичного застосування і необхідністю прийняття рішень. За таких умов необхідно зменшити частку прямої подачі інформації та розширити застосування інтерактивних форм і методів роботи іноземних студентів під керівництвом викладача, що особливо важливо для системи дистанційного навчання та повноцінної самостійної роботи «біля ліжка хворого» [9, с. 233]. У клініці переважна більшість студентів факультету підготовки іноземних громадян вперше бачать реальну загрозу від терапевтичної патології та необхідність достатніх знань для надання адекватної допомоги [1, с. 3]. Осмислення реальних подій є найкращою мотивацією до самоусвідомлення необхідності здобуття теоретичних знань і практичних навиків. Проте на даному етапі отримання медичної освіти студент-іноземець не може самостійно не тільки працювати, а й знаходитися у клініці без наставника. Неправильна поведінка 3 хворим або персоналом переважно призводить до небажаних конфліктів i негативних емоцій, що $є$ недопустимо на цьому етапі, коли у студента іноземного факультету здійснюється самовизначення професійної спеціалізації. Допомогти студенту в ознайомленні 3 терапевтичною клінікою та сприяти його науковій роботі може студентський науковий гурток. Іноземні студенти, які об'єднуються та добровільно займаються науковою роботою у студентському гуртку, спрямоване на підвищення їх наукового потенціалу та формування у них навичок науково-дослідної діяльності [5, с. 13]. Участь іноземних студентів у науковому гуртку сприяє поглибленню та закріпленню вже отриманих професійних знань, розвитку творчого мислення, формуванню зацікавленості в науковій роботі та наданню можливості самореалізації студента як в інтелектуальному, так i у творчому напрямках. Самостійна робота $\epsilon$ необхідною складовою сучасного педагогічного про- 
цесу та не є особистою справою самого студентаіноземця, а керується завданнями професорськовикладацького колективу, що має визначальне значення у зв'язку із запровадженням Болонського процесу [4, с. 101].

Мета роботи: оцінити значення функціонування студентського наукового гуртка у вищому медичному навчальному закладі як потужного i надійного засобу підготовки наукових кадрів університету.

Матеріали та методи. Проведення наукового гуртка зі студентами факультету підготовки іноземних громадян на кафедрі внутрішньої медицини №2 та медсестринства Івано-Франківського національного медичного університету викликає у студентів зацікавленість, оскільки кафедра розміщена на базі обласного клінічного кардіологічного центру, центральної міської клінічної лікарні та обласної клінічної лікарні, які є показовими клінічними базами 3 достатнім рівнем оснащення, що ефективно використовується при викладанні дисципліни внутрішньої медицини. У лікувальних установах у студентів-іноземців $\epsilon$ можливість ознайомитися 3 кабінетами функціональної діагностики, ендоскопії, рентгенологічним відділенням, 3 кабінетом рентгено-комп'ютерної біохімічної діагностики, відділенням гемодіалізу та центром реабілітації та відновного лікування.

Результати дослідження. Щорічно у студентському гуртку 3 внутрішньої медицини кафедри внутрішньої медицини №2 та медсестринства займаються близько 50 студентів V-VI курсів, які виявляють бажання додатково підвищувати свій професійний та інтелектуальний рівні. Це активні та допитливі студенти 3 невичерпною енергією та великим потенціалом творчості. Терапевтичний студентський гурток має за мету не тільки продемонструвати та розібрати цікаві клінічні випадки захворювань, глибше розглянути заплановану наукову тему, але й дає можливість кожному охочому студенту реалізувати свої можливості, розвинути своє клінічне мислення та підвищити рівень знань. 3 такою метою активно застосовується залучення іноземних студентів до самостійної роботи. Для виконання індивідуальної роботи студентів-гуртківців на початкових зібраннях викладачами застосовується диференційований підхід: установлюється рівень набутої впродовж навчання інформаційної бази, знань та технічних можливостей іноземного студента. За бажанням гуртківця передбачається його участь у науковій роботі, організації власних наукових, пошукових у літературі досліджень, 3 наступною публікацією своїх напрацювань, а також 3 можливістю демонстрації його отриманих результатів на науково-практичних конференціях молодих вчених, студентів як у межах вищого навчального закладу, де навчається, так і в межах закордонних медичних закладів. Менш ініціативні гуртківці мають можливість розвивати свої пізнавальні здібності у підготовці та демонстрації презентацій за рекомендованими керівником чи обраних за особистим переконанням тематиках, які матимуть поглиблене вивчення певної проблеми. Викладення цікавих клінічних випадків, які традиційно демонструються на кожному засіданні, на перших зібраннях проводять самі викладачі, а надалі ця можливість надається охочим гуртківцям. Такий підхід розвиває здібності доповідача у більш звичній обстановці, вчить послідовності та системності викладення інформації, сприяє розвитку інформаційної пошуковості, особливо 3 інтернету, а також навчає або вдосконалює техніку створення презентаційного викладання матеріалу. Окрім вказаних найбільш поширених форм індивідуальної роботи, іноземні студенти-гуртківці можуть вносити пропозиції інших іiі варіантів, як, наприклад, організація присвячених до певної події, хвороби чи іншої проблеми флешмобів, просвітницьких акцій тощо. Сучасна молодь характеризується більшою цілеспрямованістю, наполегливістю, сміливістю, швидко опановує новітні інформаційні технології, тому запропоновані нові форми індивідуальної роботи можуть виноситися на обговорення засідання гуртка і мати в подальшому перспективу нового напрямку.

Під час проведення засідань студентського гуртка вагому увагу приділяють формуванню деонтологічних принципів майбутніх фахівців. Розглядаються не тільки позитивні сторони поведінки лікаря, але й можливі близькі чи віддалені негативні результати, за яких слід враховувати особливості особистості хворого, сприйняття ним інформації, наданої всім медичним персоналом. Важливо на прикладах демонструвати дію теплого, співчутливого слова на пацієнта як найціннішого фактору лікування хворого та віри в одужання.

Обговорення результатів. Значне формування поваги та любові до майбутньої професії повинне мати тверде підгрунтя, що поєднуватиме працьовитість, терпимість, рішучість, толерантність, обізнаність, комунікабельність, уважність, чуйність, тактовність, великодушність, ввічливість, колегіальність, чесність, педантичність, наполегливість, витримку лікаря. У роботу студентського гуртка повинні бути залучені всі викладачі кафедри, особливо ті, які чергують у стаціонарі в ургентні дні [7, с. 161]. Студенти-іноземці, згідно з графіком чергувань, можуть не «самостійно», а 3 наставником освоювати знання і практичні навички 3 терапії та догляду за хворими терапевтичного профілю. У формуванні майбутнього фахівця викладачам слід розвивати співчуття та прививати їм відчуття обов'язку. Саме над формуванням даних рис майбутнього лікаря проводиться робота викладачами Івано-Франківського національного медичного університету, які викладають клінічні дисципліни, деонтологію та курують виробничою практикою на різних курсах. Під час проведення засідань наукового гуртка наголошується увага на необхідності щоденного поповнення знань, удосконалення своєї майстерності, примноження знань, невпинного самовдосконаленням. Отримавши диплом лікаря, необхідно вчитися все життя [6, с. $164 ; 8$, с. 360$]$.

Перспективним розділом роботи студентських наукових гуртків $є$ залучення студентів іноземного факультету до організації та проведення семінарівпрактикумів, тренінгів та майстер-класів 3 внутріш- 
ньої медицини, на яких учасники можуть практикувати основні терапевтичні маніпуляції 3 фаховими коментарями наставника.

Висновки. Студентський науковий гурток $є$ невід'ємною частиною навчального процесу у вищому медичному навчальному закладі, який уможливлює активне виконання самостійної роботи студентами іноземного факультету, сприяє розвитку інтелектуального та наукового потенціалу, навчає та вдосконалює набуті теоретичні і практичні навички і має визначне значення для становлення особистості майбутнього фахівця.

\section{References:}

1. Balutina KM. Uzgodjenna zasobiv osvyti z yi cylyamy yk obektyvna neobhidnist. Image of a modern teacher. 2015; 1-2: 3-5.

2. Duchkivcka IM. Innovaziyni pedagogichni tehnologii. K.: Akademvudav; 2014. 352 p.

3. Korovina IA. Studencheskoe nauchnoe obshchestvo kak prostranstvo samoobrazovatelnoy deyatelnosty. Intelligence. Innovation. Investments. Orenburg. 2014; 2 : 185-8.

4. Koshechko NV. Metoduka vukladannja u vuschiy schkoli. Nigin; 2013. 115p. Available from: http://nbuv.gov.ua/UJRN/vknutshp_2015_1_10.

5. Verbitsky V. Tehnologyzacia navchalno-vyhovnogo procesu $\mathrm{v}$ pozashkilnomu osvytnomu prostory yk pryncyp vyhovannya. 2015; 10:12-16.

6. Rashkevych YuM. Bolonskyi protses ta nova paradyhma vyshchoi osvity: monohrafiia. Lviv: Vydavnytstvo Lvivskoi politekhniky; 2014. 168 s.

7. Sandul MS. Konkurentni perevahy systemy vyshchoi osvity SShA. Naukovyi visnyk Uzhhorodskoho natsionalnoho universytetu. 2015; 4:161 - 165.

8. Slaughter S, Taylor V. Higher Education, Stratification, and Workforce Development: Competitive Advantage in Europe, the US, and Canada. 2015; 1:360.

9. Williams RU, Leahy AG de Rassenfosse, R Jensen. 21 Ranking of National Higher Education Systems. University of Melbourne, Melbourne. 2015; 3:233238 .

УДК 378.147.+614.253.4+376.68

ОПЫТ ПРОВЕДЕНИЯ НАУЧНОГО КРУЖКА

ДЛЯ СТУДЕНТОВ ФАКУЛЬТЕТА ПОДГОТОВКИ ИНОСТРАННЫХ ГРАЖДАН В ПРОФЕССИОНАЛЬНОЙ ПОДГОТОВКЕ ВРАЧА

\section{Н.В. Савчук}

Ивано-Франковский национальный медиџинский университет, кафедра внутренней медищины №2 $u$ медсестринства, г. Ивано-Франковск, Украина, ORCID ID: 0000-0002-8885-5796,

e-mail: savchuk.natalja257@gmail.com

Резюме. В статье раскрывается проблема дополнительного обучения студентов факультета подготовки иностранных граждан в студенческом научном кружке и отмечено возможность многогранного влияния на формирование врача как личности, что будет иметь большое значение для развития и раскрытия индивидуального потенциала, а также значительное повышение качества будущего специалиста.

Рассматриваются не только положительные стороны поведения врача, а именно формирование деонтологических принципов будущих специалистов, в частности демонстрации действия теплого, сочувственного слова на пациента, но и возможные близкие или отдаленные негативные результаты, при которых следует учитывать особенности личности больного, восприятия им информации, предоставленной всем медицинским персоналом. Студенты факультета подготовки иностранных граждан, согласно графику дежурств, могут не «самостоятельно», а со своим наставником осваивать знания и практические навыки по терапии и уходу за больными терапевтического профиля.

Во время проведения заседаний научного кружка отмечается вниманием необходимость ежедневного пополнения знаний, совершенствование своего мастерства и непрерывного самосовершенствования. Привлечение студентов иностранного факультета к организации и проведению семинаровпрактикумов, тренингов и мастер-классов по внутренней медицине, на которых участники могут практиковать основные терапевтические манипуляции с профессиональными комментариями наставника.

Обучение в рамках студенческого кружка позволяет плодотворно реализовывать учебную, воспитательную и развивающую функции педагогического процесса, способствует активному формированию знаний в иностранных студентов через самостоятельную работу и коллективное обсуждение, творческое мышление, развивает интеллектуальные умения, а также позволяет активно формировать профессиональные качества будущих специалистов.

Ключевые слова: научный кружок, студент, медицина, образование, наука.

UDC 378.147. +614.253.4+376.68

STUDENT SCIENTIFIC CLUB EXPERIENCE FOR FOREIGN CITIZENS TRAINING FACULTY STUDENTS IN THE PROFESSIONAL TRAINING OF THE DOCTOR

N.V. Savchuk

Ivano-Frankivsk National Medical University, Department of Internal Medicine №2 and medical school, Ivano-Frankivsk, Ukraine,

ORCID ID: 0000-0002-8885-5796,

e-mail: savchuk.natalja257@gmail.com

Abstract. The article deals with the problem of additional training of students of the Faculty of Foreign Citizens Training at the student scientific club and the possibility of multifaceted influence on the formation of a doctor as an individual. It will be of great importance for the development and disclosure of individual potential and a significant improvement of the quality of a future foreign specialist. 
Not only the positive aspects of the physician's behavior are considered, namely the formation of the deontological principles of future specialists, in particular demonstrating the effect of a warm, compassionate word on the patient, but also the possible near or far negative results, which should take into account the peculiarities of the patient's personality, the perception of the information given to all medical professionals staff.

Therapeutic student club enables each student to realize his/her own personal abilities, develop clinical thinking and increase the level of knowledge with the implementation of a differentiated approach. It establishes the level acquired during training of the information base, knowledge and technical capabilities of a foreign student, since in the medical institutions diagnostics, endoscopy, radiological department, with the office of Xray computer biochemical diagnostics, department of hemodialysis and, most importantly, the center of rehabilitation.

Foreign students, according to the schedule of duty, cannot "independently" but with a mentor to acquire knowledge and practical skills in therapy and care of patients with a therapeutic profile.

It also envisages the participation of the student in scientific work, organization of his own scientific and exploratory researches, with subsequent publication of his work, as well as with the possibility of demonstrating his obtained results at scientific and practical conferences of young scientists.
During the meetings of the scientific group, the emphasis is placed on the need for daily updating of knowledge, perfection of one's skills and continuous selfimprovement. Involvement of students from a foreign faculty in the organization and conduct of seminars, trainings and workshops in internal medicine, at which participants can practice basic therapeutic manipulations with the professional comments of the mentor.

Interesting clinical cases are presented, which develops the speaker's abilities in a more familiar setting, teaches consistency and systematic presentation of information, promotes information retrieval, and teaches or refines the technique of creating presentation-teaching material. In addition to the above, the most common forms of individual work, foreign students can submit offers of other variants, flash mobs, educational actions, etc.

Studying within the scientific student club allows to fruitfully implement the educational and developmental functions of the pedagogical process, promotes the active formation of knowledge in foreign students through independent work and collective discussion, creative thinking, develops intellectual skills, and also allows to actively develop professional skills.

Keywords: scientific club, student, medicine, education, science.

Стаття надійша в редакцію 11.02.2020 p. 